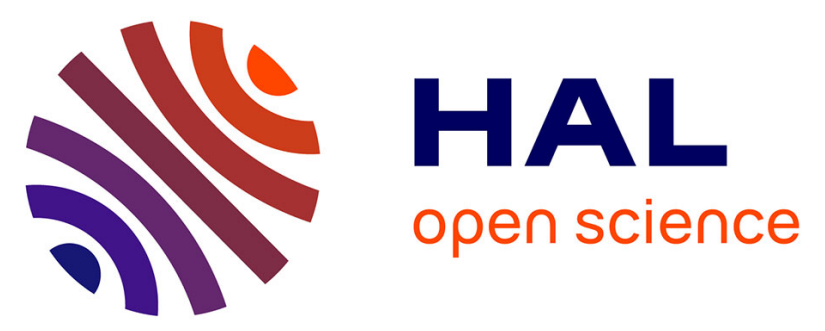

\title{
Biogeographical analysis within the family Phytoseiidae Berlese (Acari: Mesostigmata): an example from the large sub-genus Typhlodromus (Anthoseius) De Leon
}

Fabio Akashi Hernandes, Serge Kreiter, Marie-Stéphane Tixier

\section{- To cite this version:}

Fabio Akashi Hernandes, Serge Kreiter, Marie-Stéphane Tixier. Biogeographical analysis within the family Phytoseiidae Berlese (Acari: Mesostigmata): an example from the large sub-genus Typhlodromus (Anthoseius) De Leon. Acarologia, 2011, 51 (4), pp.431-448. 10.1051/acarologia/20112026 . hal-01189924

\author{
HAL Id: hal-01189924 \\ https://hal.science/hal-01189924
}

Submitted on 1 Sep 2015

HAL is a multi-disciplinary open access archive for the deposit and dissemination of scientific research documents, whether they are published or not. The documents may come from teaching and research institutions in France or abroad, or from public or private research centers.
L'archive ouverte pluridisciplinaire HAL, est destinée au dépôt et à la diffusion de documents scientifiques de niveau recherche, publiés ou non, émanant des établissements d'enseignement et de recherche français ou étrangers, des laboratoires publics ou privés. 


\title{
BIOGEOGRAPHICAL ANALYSIS WITHIN THE FAMILY PHYTOSEIIDAE BERLESE (ACARI: MESOSTIGMATA): AN EXAMPLE FROM THE LARGE SUB-GENUS TYPHLODROMUS (ANTHOSEIUS) DE LEON
}

\author{
Fabio A. Hernandes, Serge KREITER, Marie-Stéphane TIXIER*
}

(Received 05 September 2011; accepted 30 November 2011; published online 20 December 2011)

Montpellier SupAgro, Unité Mixte de Recherche CBGP (INRA/IRD/CIRAD/SupAgro), Campus International de Baillarguet, CS 30 016, 34988 Montferrier-sur-Lez cedex, France. fabio_akashi@yahoo.com.br; kreiter@supagro.inra.fr; tixier@supagro.inra.fr ( ${ }^{*}$ Corresponding author)

\begin{abstract}
Despite their great interest for pest management, the biogeography of the Phytoseiidae is still poorly known. This study focuses on the spatial distribution of one of the largest taxa within the family: the sub-genus Typhlodromus (Anthoseius) currently comprising 322 species. It also provides a description of five discrete morphological characters used to discriminate between species and easily observed. This survey is the first analysis of the combined distribution of both species and associated morphological characters within the family Phytoseiidae. It reveals the great utility of taxonomic data compilation and associated databases for aspects beyong alpha-taxonomy. The highest number of species of Typhlodromus (Anthoseius) was reported from the East Palearctic region and the lowest from the Neotropical province. This was quite surprising as the highest species diversity of Phytoseiidae is reported from this latter region. Several hypotheses are discussed to explain this observation. In provinces showing the highest number of Typhlodromus (Anthoseius) species, we usually also observed the most diverse morphological forms for the five characters considered. High endemism levels were observed in all the provinces considered, even those where only few species were reported (especially the Neotropical province). Possible synonymies are thus discussed, as species could have been described more than once in different biogeographic provinces. Furthermore, some hypotheses are discussed to explain the high species and morphological diversity of the sub-genus Typhlodromus (Anthoseius) in the West and East Palaearctic regions. Further phylogenetic analyses are required to test these different hypotheses.
\end{abstract}

KEYWORDS - biogeography; taxonomy; endemism; Gondwana; Laurasia

\section{INTRODUCTION}

The family Phytoseiidae Berlese (Acari: Mesostigmata) includes the most frequent predatory mites found on plants. Several species are used in the bio-control of mite and insect pests in several crops all over the world (McMurtry and Croft 1997; Gerson et al. 2003). It is also the family containing the highest number of known species within the or- der Mesostigmata, with more than 2,250 species described worldwide (Moraes et al. 2004; Chant and McMurtry 2007; Krantz and Walter 2009).

Despite its great interest for pest management, many aspects of Phytoseiidae distribution still remain poorly analyzed. Recently, the computerization and compilation of those data have been initiated (Tixier et al. unpub. database). Tixier et 
al. (2008a) analyzed the biogeographic distribution of the whole family, opening new perspectives for further studies on the distribution and occurrence of each genus. Indeed, understanding the distribution of taxa could help (i) in building a clearer picture of the evolutionary scenario of the considered group (Brown and Lomolino 1998; Humphries and Parenti 1999) and (ii) in more applied grounds, in searching for new predatory species to be employed in bio-control programs. This paper focuses on the biogeographic distribution of the known species of a specific sub-genus of the family Phytoseiidae, sub-family Typhlodrominae: Typhlodromus (Anthoseius) De Leon. Together, with its sister group [sub-genus Typhlodromus (Typhlodromus) Scheuten], it forms the genus Typhlodromus Scheuten, which is included in the tribe Typhlodromini with two other genera: Neoseiulella Muma and Typhloseiulus Chant and McMurtry (Chant and McMurtry 2007). The sub-genus Typhlodromus (Anthoseius), currently comprising 322 valid species and at least 20 suspected synonymies, is one of the largest within the family (Moraes et al. 2004; Chant and McMurtry 2007; Faraji et al. 2008, 2011; El-Banhawy et al. 2009; Rahmani et al. 2010; El-Banhawy and Knapp 2011; Jafari et al. 2011). Very few studies have provided revisions of this large group. Ueckermann and Loots (1988) and Ueckermann et al. (2008) revised the African species of Typhlodromus (Anthoseius). Denmark and Welbourn (2002) only listed 236 species in their world revision of the genus Amblydromella Muma, considered a junior synonym of Typhlodromus (Anthoseius) (Moraes et al. 2004, Chant and McMurtry 2007). We herein considered species of the sub-genus Typhlodromus (Anthoseius) as defined by Chant and McMurtry (2007): presence of the setae $z 3, s 6, S 5$ and absence of Z1, all dorsal setae thin, ventrianal shield not reduced (Chant and McMurtry 1994, 2007). Species of this subgenus are delimitated with some discrete characters (peritreme length, number of solenostomes on the dorsal and ventrianal shields, number of setae on the sternal and on ventrianal shields) but also with continuous characters as the dorsal and leg setal lengths (Denmark and Welbourn 2002; Ueckermann et al. 2008; Papadoulis et al. 2009; Ferragut et al. 2010).
The first objective of the present study was to provide an exhaustive survey of the geographic distribution of the known species of Typhlodromus (Anthoseius). The second objective was to determine whether the species found since now in each of the seven biogeographical provinces bear specific morphologically discrete features. Considering the low number of morphological characters available and the difficulty to encode them (especially for continuous characters), as well as the difficulty of examining all type specimens, we believe it would certainly be premature to carry out a proper phylogenetic analysis at this point. Thus, our objective was only to provide a description of the relationships between geographical distribution and morphological attributes in the aforementioned group.

\section{MATERIALS AND METHODS}

\section{Species distribution}

Data on the geographic distribution of species were obtained from the two world catalogues of the family Phytoseiidae (Moraes et al. 1986, 2004) and from subsequent papers (e.g. Bayan and Merheb 2006; Ueckermann et al. 2008, 2009; Faraji et al. 2008, 2011; El-Banhawy et al. 2009; Rahmani et al. 2010; ElBanhawy and Knapp 2011; Jafari et al. 2011). Since no geographical data was available for neither Typhlodromus (Anthoseius) wichmanni Hirschmann nor $T$. (T.) chanti Hirschmann those two species were not considered in the present analysis.

The zoogeographic provinces used in the analysis are those defined by Sclater (1858) and Wallace (1876). These areas, initially called realms, were based on the taxonomic or phylogenetic relationships of animals (especially vertebrates) and not on the adaptations to specific environments (Ebach and Humphries 2002). Despite the fact that the data used to delineate provinces were compiled long before advances in Palaeontology and the theory of Continental Drift, the basic concept of distribution and the names of the zoogeographic provinces are still in use today (Humphries and Parenti 1999; Cox 2001). The biogeographic provinces considered are as follows: Nearctic (North America excluding Florida), Neotropical (South and Central 


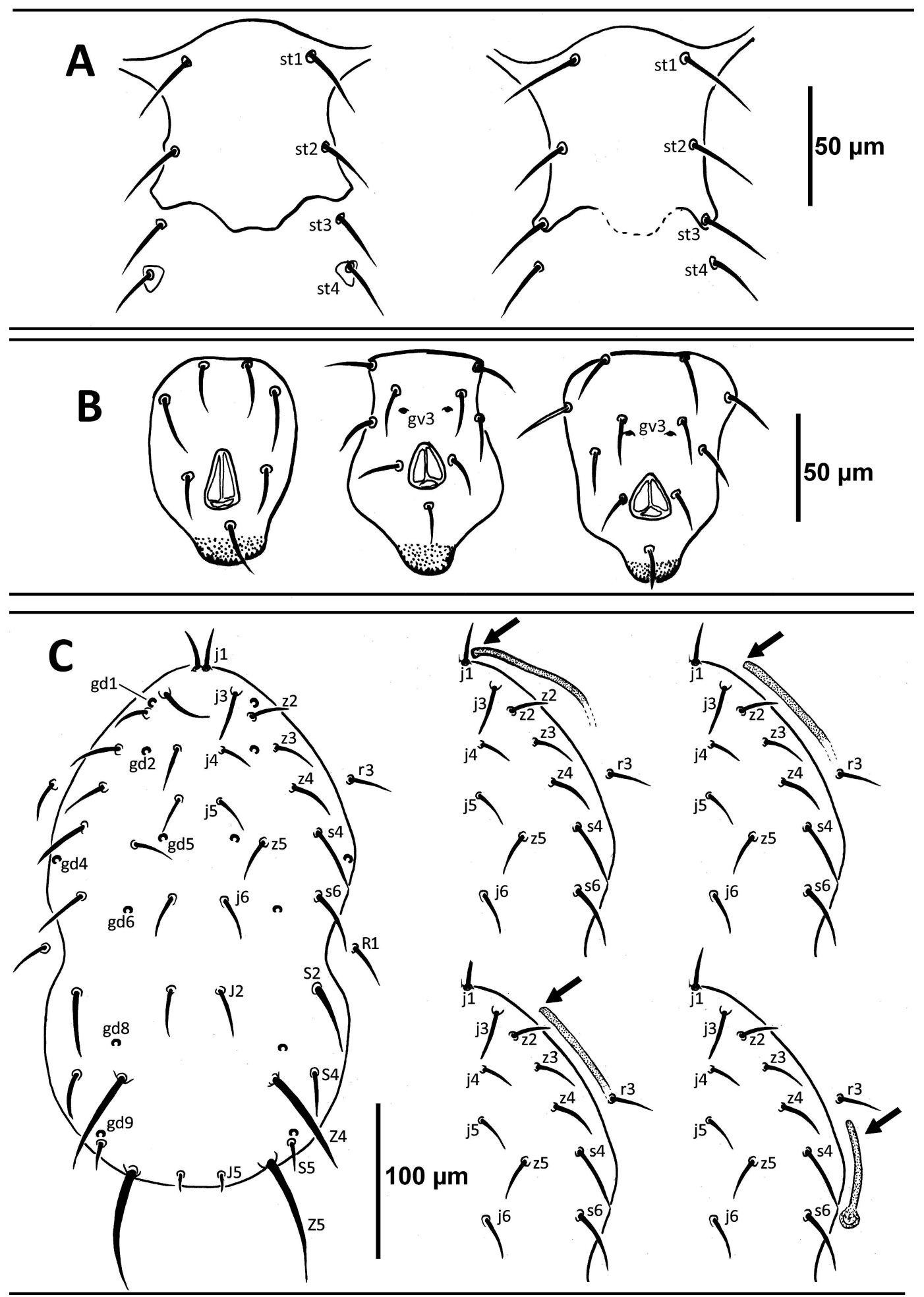

FIGURE 1: Morphological characters considered in the study of species of the sub-genus Typhlodromus (Anthoseius). A - the two sternal shield chaetotaxies (ST3 on or off the sternal shield), B - the three ventrianal shield chaetotaxies and position of the pair of pores (gv3) on the ventrianal shield, C - position and names of the dorsal setae (right-hand side of body) and solenostomes (left-hand side) and position of the peritreme endings. 
America, Caribbean islands and Florida), Oriental (Taiwan, Malaysia, Philippines, India, Southern China, Okinawa, Japan, Thailand, South Korea), Australasian (Australia, New Zealand, New Caledonia, Papua New Guinea, Pacific islands), Ethiopian (sub-Saharan Africa including Madagascar), West Palaearctic (WP: Europe extending to Ural, Northern India and Northern Africa) and East Palaearctic (EP: Asia from Ural to Japan excluding Southern China and Okinawa). Because of its large surface, the Palaearctic region was divided in two parts, namely the West Palaearctic, and the East Palaearctic (sensu lato) (Gressitt 1974; Skuhrava and Skuhravy 2009). Furthermore, studies on the distribution of the Phytoseiidae species and genera revealed that different taxa are currently observed in these two areas (Tixier et al. 2008a; Tixier and Kreiter 2009). The Wallace Line (Darlington 1957) was used to separate the Oriental and Australasian provinces.

The database used for analyses includes the occurrence (presence/absence) of 320 species among the 322 presently described in the seven biogeographic regions (appendix 1). Species numbers and endemism levels were evaluated; endemism was considered when one species was reported only from a single biogeographic province.

Jaccard similarity indices were calculated between the areas as follows: $I=C /\left(N_{1}+N_{2}-C\right)$, where $C$ is the number of species present in both areas, $N_{1}$ is the total number of species in area 1 , and $\mathrm{N}_{2}$ is the total number of species in area 2 (Brown and Lomolino 1998).

\section{Spatial distribution of characters}

Terminologies for chaetotaxy, poroidotaxy and adenotaxy used in this paper follow those proposed by Lindquist and Evans (1965) as adapted by Rowell et al. (1978) for the Phytoseiidae, and Athias-Henriot (1975), respectively.

The study of the spatial distribution of five qualitative discrete characters was carried out. We have chosen to analyze qualitative discrete characters in order to avoid interpretation errors (as it could be the case for continuous characters such as setae lengths). Furthermore, they were quite easy to observe, and at the same time universally reported in description and re-descriptions. Finally, the five characters selected are currently used in species diagnostic (Ueckermann and Loots 1988; Denmark and Welbourn 2002; Ueckermann et al. 2008). Some rare intraspecific variations were observed but further experiments for testing if these variations really correspond to intraspecific morpholines would be clearly required (Rahmani et al. 2010, Jafari et al. 2011). The characters considered were as follows:

1. number of setae on the sternal shield, some species bear two pairs (ST1 and ST2) whereas others bear three (ST1, ST2, ST3);

2. number of preanal setae on the ventrianal shield (VAS), some species bear two pairs, while others bear three or four;

3. presence of the pores $g v 3$ on the ventrianal shield;

4. number of solenostomes on the dorsal shield (ranging between one and seven: $g d 1, g d 2$, $g d 4, g d 5, g d 6, g d 8, g d 9)$;

5. peritreme length: 4 character states were considered, peritreme reaching at the levels of $j 1$, between $j 1-j 3$, between $j 3-z 2$ or between $z 4-s 4$ (Figures $1 \mathrm{~A}-\mathrm{C}$ ).

To determine the state of these five characters, we used the original descriptions but also subsequent publications to check for the stability of the character state within a same species. However, although the overall literature on the sub-genus Typhlodromus (Anthoseius) was considered, information was not equally available for all the species and characters because of the poor quality and/or succinct descriptions. For some species, inconclusive characters were thus not considered. The most problematic feature was the number of solenostomes on the dorsal shield, because sometimes this was not mentioned in the description text, and drawings were often unclear. Furthermore, some authors (e.g. Gupta 1970) referred to solenostomes as "pairs of visible pores". In those cases, again, it is not conclusive to assume that those correspond 
to solenostomes, or rather to other types of dorsal pores (e.g. poroids).

\section{RESULTS}

\section{Species distribution}

Species of the sub-genus Typhlodromus (Anthoseius) occur in the seven biogeographic provinces (Table 1). Distribution of species in these provinces are significantly different $\left(\mathrm{Chi2}{ }_{(1,6)}=210.16 ; P<0.05\right)$. Only seven species have been found in more than one biogeographic province [T. (A.) barkeri (Garman), T. (A.) caudiglans Schuster, T. (A.) persianus McMurtry, T. (A.) rhenanus (Oudemans), T. (A.) rhenanoides Athias-Henriot, T. (A.) richteri Karg and T. (A.) transvaalensis] and a single species, T. (A.) transvaalensis (Nesbitt), was reported from all of them (Table 2). The East Palaearctic province shows the highest diversity ( 99 species), followed by the Ethiopian (87 species), the West Palaearctic (63 species) and the Oriental (59 species) provinces. Conversely, relatively few species are reported from the Neotropical (10 species), Nearctic (12 species) and Australasian (11 species) provinces (Table 1).

The great majority of species (313 species; $97.8 \%$ ) are endemic to a single geographic province. Five provinces have endemism rates of at least $90 \%$
(Table 1). The highest endemism levels are observed in the four most species-rich areas (West Palaearctic, East Palaearctic, Ethiopian and Oriental) but also in the Neotropical province despite the low number of species reported in this latter area (10 species). The lowest endemism rate $(50 \%)$ is observed in the Nearctic province.

Jaccard indices were globally low, ranging from $0.93 \%$ to $15 \%$ (Table 3), which agrees with the high endemism rates previously discussed. The highest similarity rate is observed between the Nearctic and Australasian provinces (15\%) but this high rate is due to the occurrence of three species [T. (A.) bakeri, T. (A.) caudiglans, and T. (A.) transvaalensis] that are present in at least five provinces among the seven considered. The second highest similarity rate is observed between the Nearctic and West Palaearctic provinces $(7.14 \%)$. Again, among the five species common to these two provinces, four are worldwide distributed whereas a single one $T$. (A.) rhenanoides - is only present in these two regions. Similarities around $5 \%$ are noted between (i) Nearctic and Neotropical provinces $(4.76 \%)$, the single species in common, $T$. (A.) transvaalensis, is the most widespread species of the sub-genus; (ii) Australasian and Neotropical provinces [similarity of $5 \%$, one species in common: again, $T$. (A.)

TABLE 1: Number of species of the sub-genus Typhlodromus (Anthoseius) and endemism rates (\%) in the seven biogeographic provinces considered

\begin{tabular}{|c|c|c|c|c|c|c|c|}
\hline & Neotropical & Nearctic & Ethiopian & West Palaearctic & East Palaearctic & Australasian & Oriental \\
\hline Number of species & 10 & 12 & 87 & 63 & 99 & 11 & 59 \\
\hline Number of endemic species & 9 & 6 & 83 & 57 & 95 & 8 & 55 \\
\hline$\%$ endemism / species of each zone & $90 \%$ & $50 \%$ & $95 \%$ & $90 \%$ & $96 \%$ & $73 \%$ & $93 \%$ \\
\hline$\%$ endemism / total of species & $3 \%$ & $2 \%$ & $26 \%$ & $18 \%$ & $30 \%$ & $3 \%$ & $17 \%$ \\
\hline
\end{tabular}

TABLE 2: Species of the sub-genus Typhlodromus (Anthoseius) occurring in more than one biogeographic province.

\begin{tabular}{|c|c|c|c|c|c|c|c|}
\hline & Neotropical & Nearctic & Ethiopian & West Palaearctic & East Palaearctic & Australasian & Oriental \\
\hline T.(A.) bakeri & & $\mathrm{x}$ & & $\mathrm{x}$ & $\mathrm{x}$ & $\mathrm{x}$ & $\mathrm{x}$ \\
\hline T.(A.) caudiglans & & $\mathrm{x}$ & $\mathrm{x}$ & $\mathrm{x}$ & $\mathrm{x}$ & $\mathrm{x}$ & \\
\hline T.(A.) persianus & & & $\mathrm{x}$ & $\mathrm{x}$ & & & \\
\hline T.(A.) rhenanoides & & $\mathrm{x}$ & & $\mathrm{x}$ & & & \\
\hline T.(A.) rhenanus & & $\mathrm{x}$ & $\mathrm{x}$ & $\mathrm{x}$ & & & $\mathrm{x}$ \\
\hline T.(A.) rickeri & & $\mathrm{x}$ & & & $\mathrm{x}$ & & $\mathrm{x}$ \\
\hline T.(A.) transvaalensis & $\mathrm{x}$ & $\mathrm{x}$ & $\mathrm{x}$ & $\mathrm{x}$ & $\mathrm{x}$ & $\mathrm{x}$ & $\mathrm{x}$ \\
\hline
\end{tabular}


TABLE 3: Similarity indices of Jaccard (\%) between the seven biogeographic provinces and species of the sub-genus Typhlodromus (Anthoseius).

\begin{tabular}{lccccc}
\hline & Neotropical & Nearctic & Ethiopian & West Palaearctic East Palaearctic Australasian \\
\hline Nearctic & 4.76 & & & & \\
Ethiopian & 1.04 & 3.13 & & & \\
West Palaearctic & 1.38 & 7.14 & 2.74 & & \\
East Palaearctic & 0.93 & 3.74 & 1.09 & 2.89 & 2.80 \\
Australasian & 5.00 & 15.00 & 2.08 & & \\
Oriental & 1.47 & 5.97 & 1.39 & 2.52 & 1.94 \\
\hline
\end{tabular}

transvaalensis]. Finally, four species are simultaneously found in the Nearctic and Oriental provinces (similarity of $5.97 \%$ ). However, again these species are the most worldwide distributed.

\section{Spatial character distribution}

Number of setae inserted on the sternal shield.

The number of species with two pairs (157 species) of setae on the sternal shield is slightly higher than the number of species bearing three pairs (139 species) (Figure 2). Species with two pairs are particularly numerous in the Ethiopian (52 species) and West Palaearctic provinces (45 species) where

\section{$\%$ species}
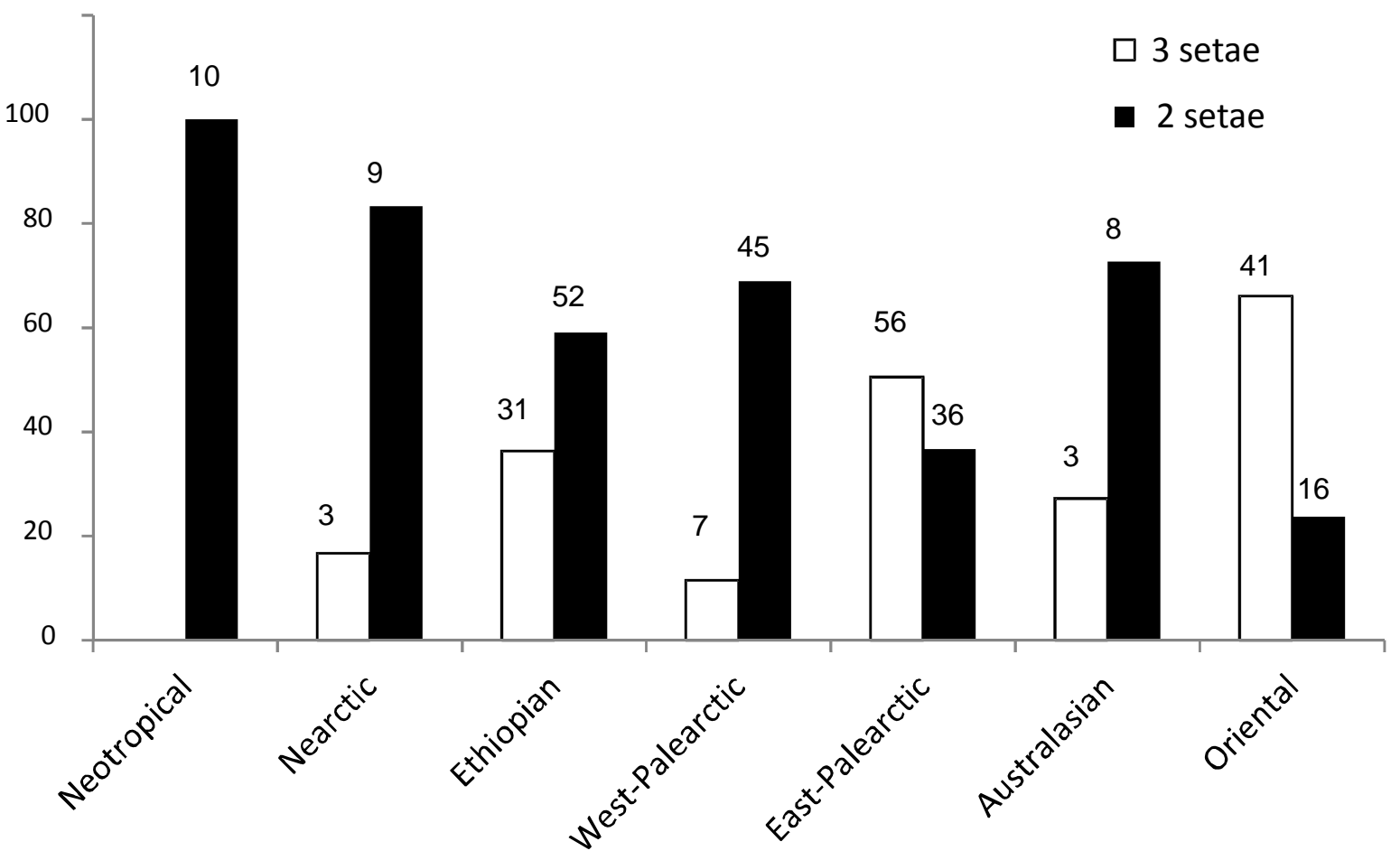

FIGURE 2: Number (above the bars) and percent of species of the sub-genus Typhlodromus (Anthoseius) with two or three pairs of setae on the female sternal shield in the seven biogeographic provinces considered. 
they constitute the prevailing species. Species with two pairs of setae are also numerous in the East Palaearctic and Oriental provinces; however, in those areas they do not constitute the prevailing ones. No species with three setae on the sternal shield is reported from the Neotropical province and very few in the Nearctic and Australasian areas (Figure 2).

Number of setae inserted on the ventrianal shield (VAS).

Most species of Typhlodromus (Anthoseius) (280 species) have four pairs of pre-anal setae on the $V A S ; 31$ species have three pairs whereas only four species have two (Figure 3). Species with four or three pairs are reported from all the seven provinces. However, they tend to be more numerous in the Palaearctic (both East and West), Oriental and Ethiopian provinces, which might be simply due to the higher number of species found in those provinces. Considering thus the percent of species bearing these features in each province (Figure 3 ), the proportion of species with four setae on the VAS exceeds $80 \%$ in all the provinces, except in the Neotropical and Nearctic provinces. Furthermore, in this latter province, $33.3 \%$ of the endemic species have three setae whereas $66.6 \%$ have four. One hundred percent and $77.8 \%$ of endemic species have four setae on the VAS in the Australasian and Neotropical provinces, respectively. No clear delineation between geographical provinces regarding the presence of four or three setae on the VAS is thus visible. However, the four species with two setae on the VAS have only been recorded in the Palaearctic and Ethiopian provinces (Figure 3): T. (A.) ilicisAthias-Henriot in Morocco, France and Algeria (Athias-Henriot 1960, McMurtry and Bounfour 1989), T. (A.) monosetus Wang and $\mathrm{Xu}$ from China (Wang and Wu 1991), T. (A.) povtari(Kolodochka) in Russia (Kolodochka 1988), and T. (A.) noonus ElBanhawy and Knapp from Kenya (El-Banhawy and Knapp 2011).

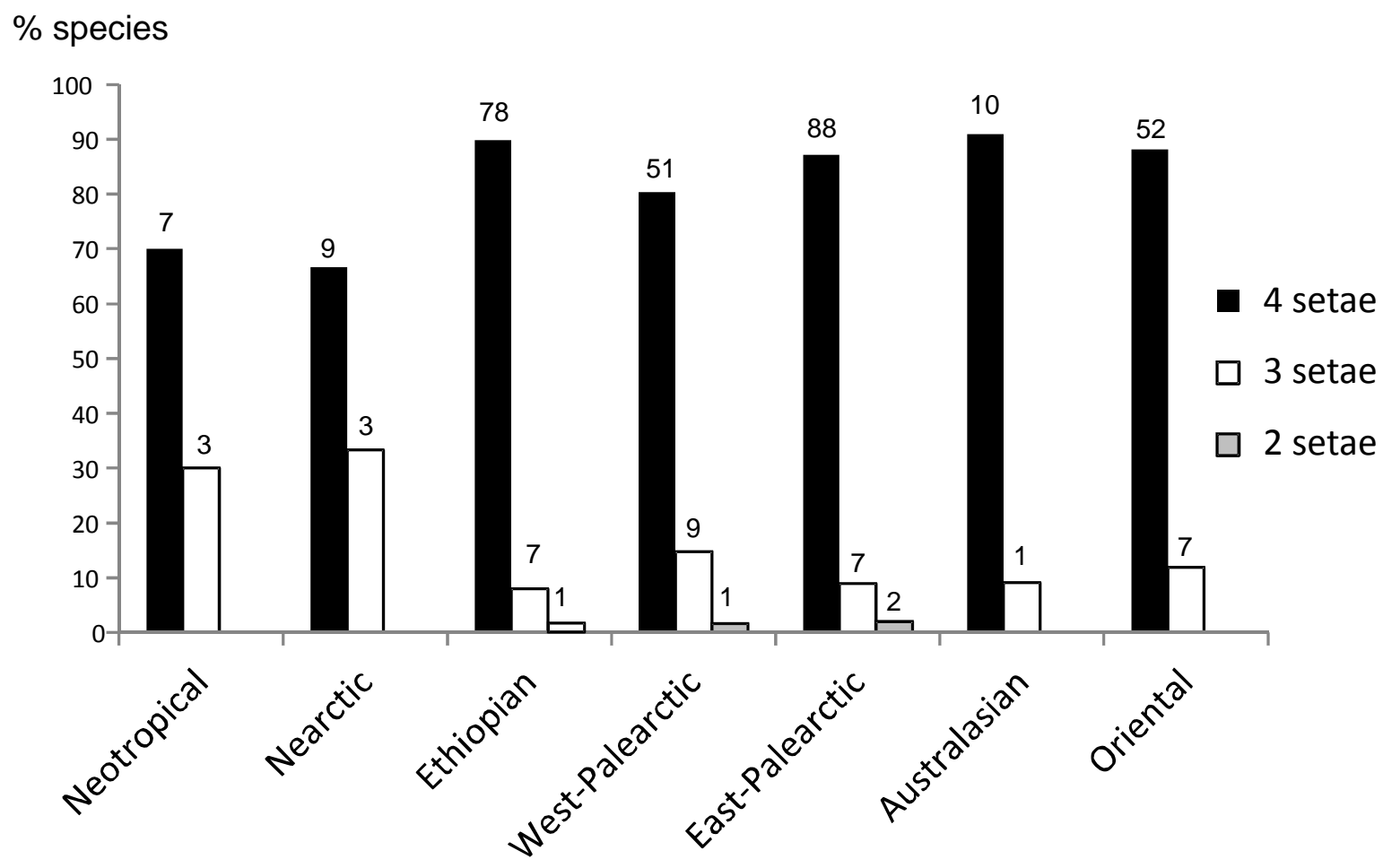

FIGURE 3: Number (above the bars) and percent of species of the sub-genus Typhlodromus (Anthoseius) with two, three or four pairs of preanal setae on the female ventrianal shield in the seven biogeographic provinces considered. 
Presence of pores gv3 on the ventrianal shield.

gv3 Most species (262 species) of the sub-genus Typhlodromus (Anthoseius) have a pair of pores gv3 on the ventrianal shield. These species are found mostly in the East Palaearctic (82 species), Ethiopian (80 species), Oriental (50 species), and West Palaearctic (40 species) provinces (Figure 4). Species reported from the Australasian and Nearctic provinces all bear a pore, as well as the majority of the Neotropical species.

Number of solenostomes on the dorsal shield.

The majority of the species of Typhlodromus (Anthoseius) for which this feature could be observed, has five solenostomes on the dorsal shield (126 species). They are found in all the seven geographic provinces, the highest number being reported from the Ethiopian (58 species) and the Palaearctic provinces (EP: 33 species, WP: 30 species) (Figure
5). Species with four solenostomes (24 species) are particularly numerous in the Palaearctic provinces (11 species in EP and 8 in WP). Species with three solenostomes are absent from the Neotropical zone, again these species are more commonly found in the Palaearctic provinces. Four species have only one solenostome $(g d 2)$, one is reported from the WP province [Typhlodromus (Anthoseius) serratus (Chaudhri)], two from EP [T. (A.) balakotiensis (Chaudhri, Akbar and Rasool) and T. (A.) zafari Chaudhri], and finally one from the Neotropics [T. (A.) tecoma (Denmark and Evans)]. Only two species have two solenostomes ( $g d 2$ and $g d 8)[T$. (A.) luzonensis Schicha and Corpuz-Raros and T. (A.) manipurensis (Gupta)]. However, for this latter species nothing was mentioned in the original description and this feature was inferred from the drawings. Finally, two species, T. (A.) umbratus (Chaudhri, Akbar and Rasool) and T. (A.) noonus El-Banhawy and

\section{$\%$ species}

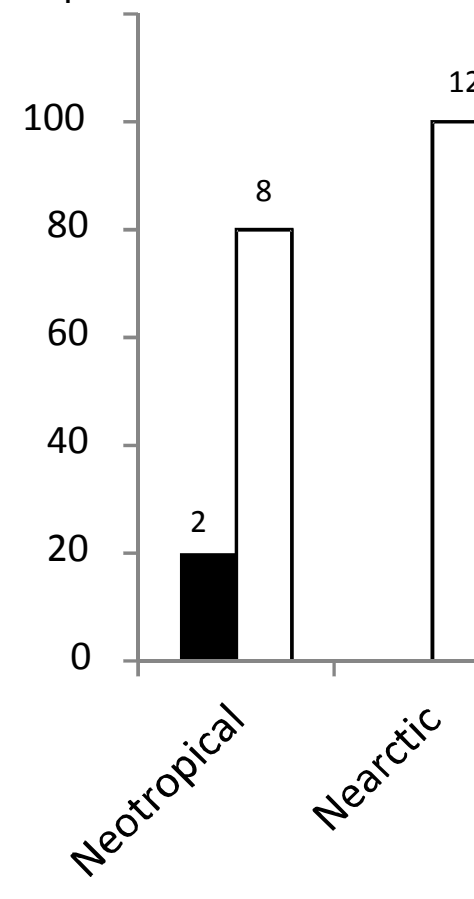

12

80

80<smiles>CC</smiles>

Pore gv3 present

11 


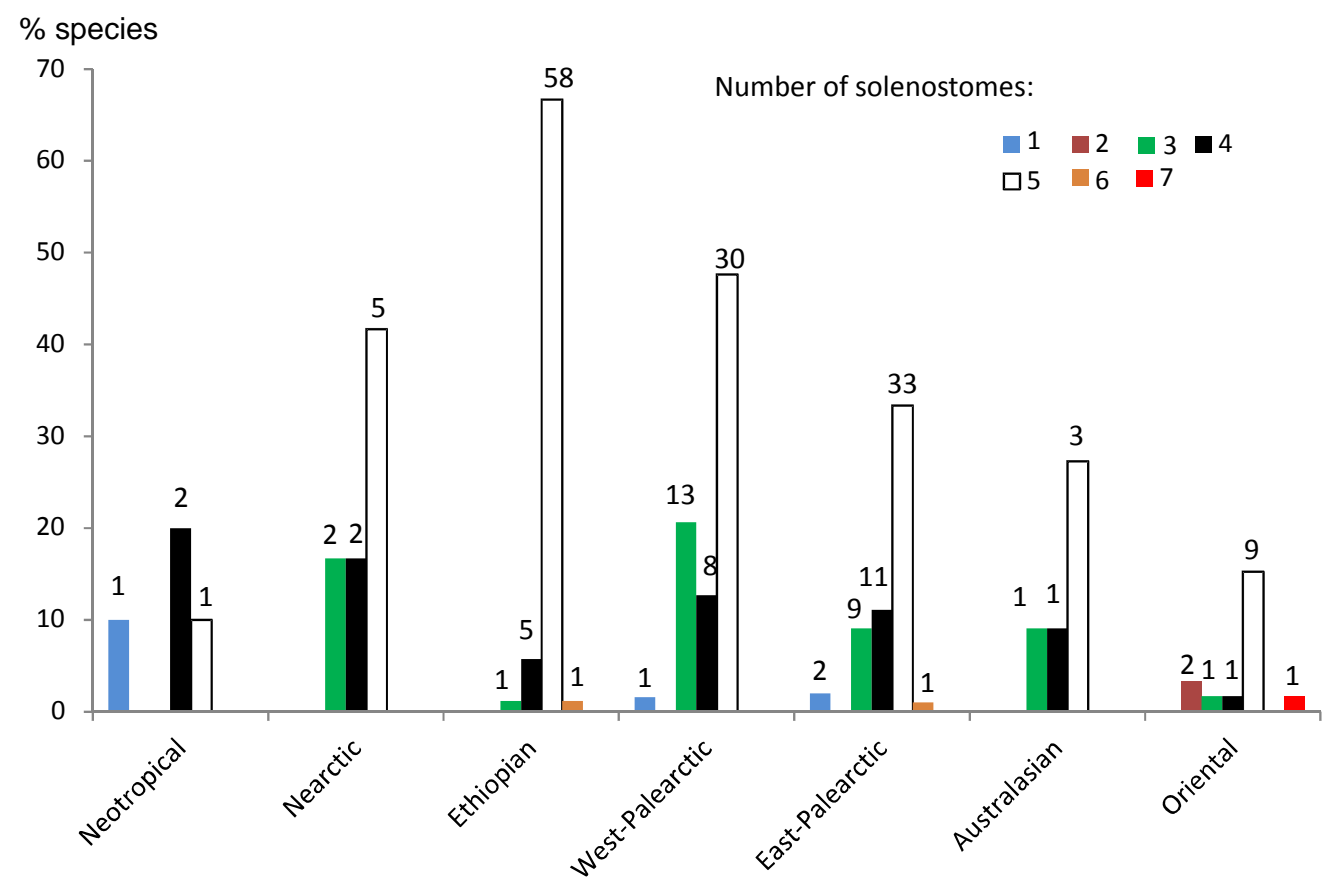

FIGURE 5: Number (above the bars) and percent of species of the sub-genus Typhlodromus (Anthoseius) with one to seven solenostomes on the female dorsal shield in the seven biogeographic provinces considered.

Knapp are reported to have 6 solenostomes, the former being endemic to the East Palaearctic province and the latter endemic to the Ethiopian region. Only one species, endemic to the Oriental province, has 7 solenostomes [T. (A.) pruni Gupta] (Figure 5).

Regions showing the highest diversity in the number of solenostomes are the Oriental, Ethiopian and the two Palaearctic provinces.

\section{Peritreme length.}

In most of the species (216 species), the peritreme reaches the level of the dorsal setae $j 1$; only relatively few species show other positions. Species with this feature are numerous in all the provinces (Figure 6). Most of the species endemic to the Australasian and Neotropical provinces have the peritreme at $j 1$ position. Species with the shortest peritreme (15 species in total), i.e. reaching the level of dorsal setae $z 4$ to $s 4$, are only present in the Palaearctic (8 species in WP, 3 species in EP), Oriental (3 species) and the Nearctic (1 species) provinces. Two types of peritreme are observed in species endemic to the Australasian province, and three in the endemic species of the Nearctics and Neotropics (Figure 6).

\section{DISCUSSION}

This study focusing on the sub-genus Typhlodromus (Anthoseius) is the first one proposing combined analyses of the distribution of both species and morphological associated characters within the family Phytoseiidae. It clearly shows the utility of taxonomic data compilation and associated databases in broader aspects than only alpha-taxonomy (Meier and Dikow 2004).

This survey first emphasizes the worldwide distribution of T. (A.) transvaalensis. This species is found in many habitats including stored products (Amitai and Swirski 1978; Corpuz-Raros et al. 1988), and its wide distribution could be explained by the shipment of food from country to country.

The highest number of species of the sub-genus Typhlodromus (Anthoseius) was found in the whole Palaearctic region, whereas the lowest was reported 


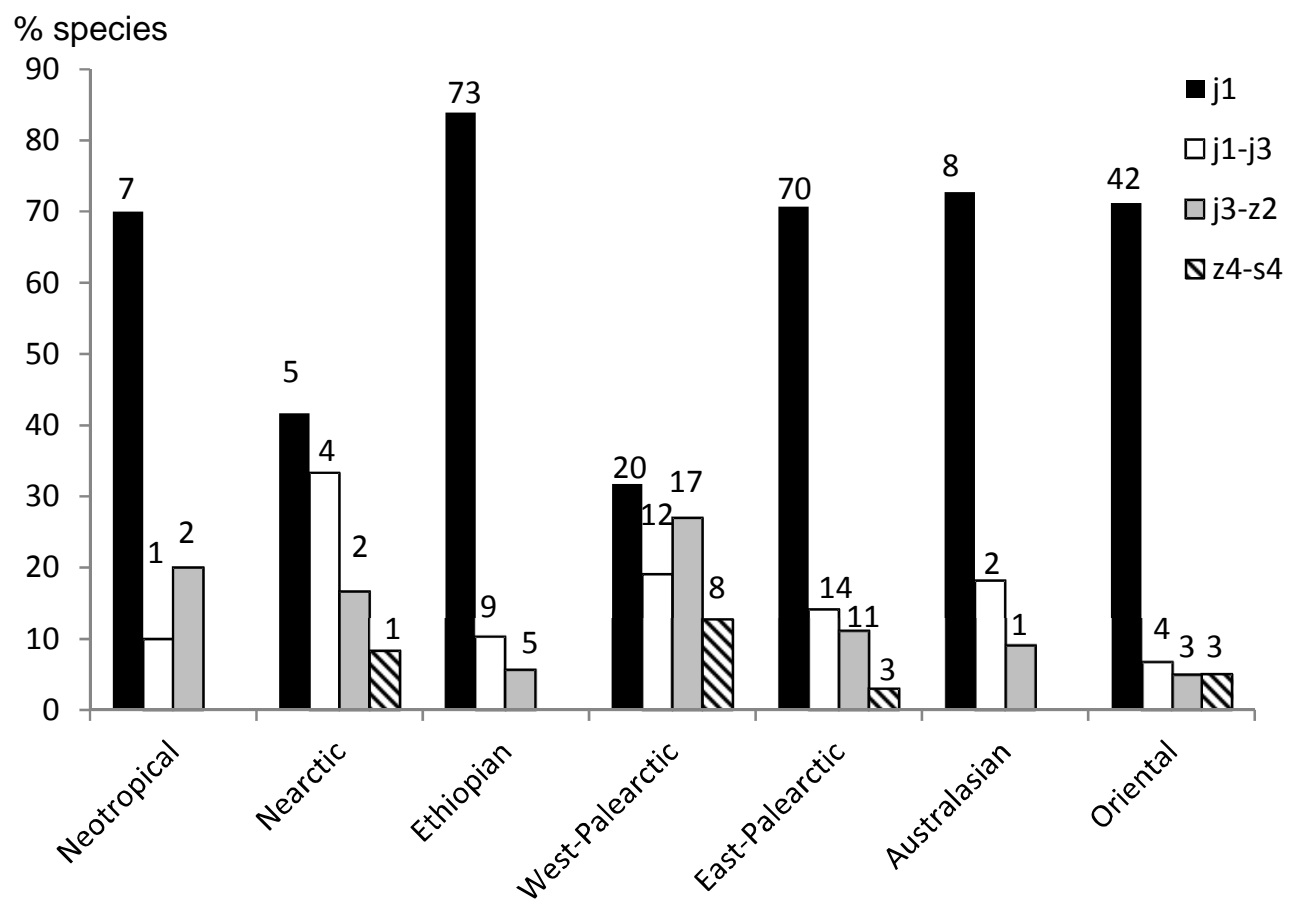

FIGURE 6: Number (above the bars) and percent of species of the sub-genus Typhlodromus (Anthoseius) having five different female peritreme lengths in the seven biogeographic provinces considered.

in the Neotropical province. This is quite surprising as this latter province contains the highest number of Phytoseiidae species reported to date (Tixier et al. 2008a). So one can wonder why a high diversity of Typhlodromus (Anthoseius) was not also observed in this area. Is it because species of this sub-genus have not been found yet in this province? In our opinion this hypothesis is weakly sustained, as the number of surveys carried out in the Neotropics is much higher than in other areas (Moraes et al. 2004; Tixier et al. 2008a; Tixier and Kreiter 2009). We could thus suggest other hypotheses as (i) species of this sub-genus did not colonize this province or (ii) have been extinct. Similarly, the number of species of Typhlodromus (Anthoseius) is also low in the Nearctics. The same hypotheses as those previously developed for the Neotropics could also be raised to explain the low number of species reported in the Nearctics.

The most diverse morphological forms of Typhlodromus (Anthoseius) have been observed in the two Palaearctic areas. This could appear quite logical.
Indeed, in provinces where the number of species of Typhlodromus (Anthoseius) was low, the number of morphological forms was also low (e.g.Neotropical and Australasian provinces) and vice versa. However, despite a great number of species reported in the Ethiopian province and in a less extent in the Oriental one, the number of morphological forms is much lower than in the Palaearctic provinces. This could suggest that only some morphological forms succeeded in colonizing these two former provinces, nevertheless with a great success in regards to the occurrence of many species. Other hypotheses could be that these forms have not been found yet or that they would have been extinct.

In the West and East Palaearctic provinces, we also observed rare character states (two setae on the ventrianal shield, short peritreme). The highest number of species and morphological diversity, as well as some rare characters in these latter provinces could suggest that these parts of the world are the centre of origin of the sub-genus. The distribution of the three other genera of the tribe 
(Typhlodromini) [in which is included Typhlodromus (Anthoseius)] seems to concur to this hypothesis (Moraes et al. 2004; Tixier et al. 2008a). Indeed, all species of the genus Typhloseiulus Chant and McMurtry [same dorsal chaetotaxy as Typhlodromus (Anthoseius)] are reported from the West Palaearctic area; species of the sister sub-genus, Typhlodromus (Typhlodromus) Scheuten, are mainly reported from the Palaearctic province $(60 \%$ and $14 \%$ of species from the West and East Palaearctic areas, respectively); and $38 \%$ of the species the genus Neoseiulella Muma are endemic to the West Palaearctic region. Furthermore, Kanouh (2010) questioned the polyphyly of this latter genus to explain that $50 \%$ of species are endemic of the Australasian province. However, as high diversity and endemism in the Palaearctic provinces can be due to other factors, i.e. extinctions in the other provinces (Cain 1944; Brown and Lomolino 1998; Humphries and Parenti 1999), additional phylogenetic studies would be thus required to test the hypothesis presently discussed.

Finally, the present study emphasizes high endemism levels in all the provinces considered, even those where only few species were reported (i.e. Neotropics). Organisms can be endemic to a location because they originated in that place and never dispersed but also because they can be extinct in the original area and only survive in the secondary colonized zones (Brown and Lomolino 1998). Biology and history of species of Typhlodromus (Anthoseius) is poorly known, thus it would be highly speculative to try to explain the endemism rates. Our own experience suggests however that species of Typhlodromus (Anthoseius) are rare and when found the number of specimens is low. For instance, 269 species have been reported less than four times, whereas six species (the worldwide ones) have been reported more than 30 times. Finally, the high endemism rates at species level could also be due to an artefact. Indeed, the morphological features that really allow to discriminate between species within the family Phytoseiidae, and as a consequence in the sub-genus Typhlodromus (Anthoseius), are sometimes questionable (Tixier et al. 2003, 2006a, b, 2008b, 2010; Okassa et al. 2009, 2010). We can thus wonder if the number of synonymies which is presently very low $(6 \%)$ would not be in reality much higher. Many species described or only reported from one province may have actually been described more than once from another province (under another name). Furthermore, many species have been described based on few specimens thus it is quite difficult to determine a posteriori if this is really a new species or a variant of a known one. Moreover, for some authors it could have been difficult to assess the huge taxonomic information (322 original descriptions in 58 countries and in nearly a dozen languages). To better assess the level of synonymy, different studies on this sub-genus are planned. At first, molecular experiments will be conducted to assess the reliability of some morphological characters presently used for diagnosis; a DNA sequence database will be built to assist diagnosis (La Salle et al. 2009). However, the main difficulty presently encountered is the collection of live material, given the rarity of the species. The second work consists in a compilation of the morphological characters of all the species of this sub-genus in order to construct an electronic polytomous key intended to be freely accessible on the web in order to facilitate the identification of the species of Typhlodromus (Anthoseius) and to avoid the description of species already known.

\section{ACKNOWLEDGEMENTS}

We are very grateful to the three anonymous referees for their comments that greatly improved the quality of the paper.

\section{REFERENCES}

Amitai S., Swirski E. 1978 - A new genus and new records of phytoseiid mites (Mesostigmata: Phytoseiidae) from Israel — Isr. J. Entomol., 12: 123-143.

Athias-Henriot C. 1960 - Nouveaux Amblyseius d'Algérie (Parasitiformes, Phytoseiidae) - Acarologia, 2: 288-299.

Athias-Henriot C. 1975 - Nouvelles notes sur les Amblyseiini. II. Le relevé organotaxique de la face dorsale adulte (Gamasides, Protoadéniques, Phytoseiidae) Acarologia, 27: 20-29.

Bayan A., Merheb B. 2006 - Descriptions of two new phytoseiid mites (Acari: Mesostigmata: Gamasina) 
found in a grapevine orchard from Lebanon - Syst. Appl. Acarol., 11: 51-56.

Brown J.H., Lomolino M.V. 1998 - Biogeography; 2nd edition - Sinauer associates, Inc., Publishers Sunderland, Massachussets. pp. 691.

Cain S.A. 1944 - Foundations of plant geography New York Harper and Brothers.

Chant D.A., McMurtry J.A. 2007 - Illustrated keys and diagnoses for the genera and subgenera of the Phytoseiidae of the world (Acari: Mesostigmata) - Indira Publishing House, pp. 220.

Corpuz-Raros L.A., Sabio G.C., Velasco-Soriano M. 1988 - Mites associated with stored products, poultry houses and house dust in the Philippines - Philippine Entomologist, 7: 311-321.

Cox B. 2001 - The biogeographic regions reconsidered - J. Biogeogr., 28: 511-523. doi:10.1046/j.13652699.2001.00566.x

Darlington P.J. 1957 - Zoogeography: the geographical distribution of animals - Wiley, New York and London.

Denmark H.A., Welbourn W.C. 2002 - Revision of the genera Amblydromella Muma and Anthoseius De Leon (Acari: Phytoseiidae) - Internat. J. Acarol., 28(4): 291-316. doi:10.1080/01647950208684308

Ebach M.C., Humphries C.J. 2002 - Area cladistics: discovering the relative positions of continents through time - J. Biogeogr., 29: 427-444. doi:10.1046/j.13652699.2002.00687.x

El-Banhawy E.M., Irungu L., Mugo H. 2009 - Survey of predacious mites (Acari: Phytoseiidae) inhabiting coffee trees in Kenya with descriptions of some new species - Acarologia, 50: 121-137.

El-Banhawy E.M., Knapp M. 2011 - Mites of the family Phytoseiidae Berlese from Kenya (Acari: Mesostigmata) - Zootaxa, 2945: 1-176.

Faraji F., Roig J., Bakker F. 2011 - Some new records of Phytoseiidae from South-West Europe with description of a new species From Spain (Acari: Mesostigmata) - Internat. J. Acarol., 37; 331-346.

Faraji F., Bakker F., Roig J. 2008 - A new species and two new records of Phytoseiidae (Acari: Mesostigmata) from Spain - Rev. Iber. Aracnol., 16: 105-111. doi:10.1080/01647954.2010.519722

Ferragut F., Perez-Moreno I., Iraola V., Escudero A. 2010 - Acaros depredadores en las plantas cultivadas. Familia Phytoseiidae - Ediciones Agrotecnicas S.L. Madrid. pp. 202.

Gerson U., Smiley R.L., Ochoa R. 2003 - Mites (Acari) for pest control - Oxford (UK): Blackwell Publishing. pp. 537. doi:10.1002/9780470750995
Gressitt J.L. 1974 - Insect biogeography Annu. Rev. Entomol., 19: 293-321. doi:10.1146/annurev.en.19.010174.001453

Gupta S.K. 1970 - Some predatory mites of the family Phytoseiidae from West Bengal, India (Acarina: Mesostigmata) — Orient. Insects, 4: 185-191.

Humphries C.J., Parenti L.R. 1999 - Cladistic biogeography. Interpreting patterns of plant and animal distribution. 2nd edition - Oxford University Press. Editors. Hallam A., Rosen B.R., Whitmore T.C., pp. 187. doi:10.1080/01647954.2010.514288

Jafari S., Fathipour Y., Faraji, F. 2011 - Re-descriptions of Amblyseius meghriensis Arutunjan and Typhlodromus haiastanius (Arutunjan) with discussion on using preanal pores as a character in the subgenus Anthoseius (Mesostigmata: Phytoseiidae) - Internat. J. Acarol., 37: 244-254.

Kanouh M. 2010 - Etudes taxonomiques de deux genres d'acariens prédateurs de la famille des Phytoseiidae (Acari : Mesostigmata): Phytoseiulus Evans et Neoseiulella Muma - PhD dissertation, Montpellier SupAgro, pp. 304.

Kanouh M., Tixier M.-S., Guichou S., Cheval B., Kreiter S. 2010 - Two synonymy cases within the genus Neoseiulella (Acari: Phytoseiidae): is the molecular evidence so evident? - Biol. J. Linn. Soc., 101(2): 323344. doi:10.1111/j.1095-8312.2010.01516.x

Kolodochka L.A. 1988 - A new genus and a new species of the mite family Phytoseiidae (Parasitiformes) Vestn.Zool., 4: 42-45.

Krantz G.W., Walter D.E. 2009 - A manual of acarology. 3rd ed - Lubbock (TX): Texas Tech University Press. pp. 807.

La Salle J., Wheeler Q., Jackway P., Winterton S., Hobern D., Lovell D. 2009. Accelerating taxonomic discovery through automated character extraction - Zootaxa, 2217: 43-55.

Lindquist E., Evans G.W. 1965 - Taxonomic concepts in the Ascidae, with a modified setal nomenclature for the idiosoma of the Gamasina Acarina: Mesostigmata - Mem. Entomol. Soc. Can., 47: 1-64. doi:10.4039/entm9747fv

McMurtry J.A., Bounfour M. 1989 - Phytoseiid mites of Morocco, with descriptions of two new species and notes on the genera Kuzinellus, Typhloctonus and Typhlodromus (Acari: Phytoseiidae) - Acarologia, 30(1): 13-24.

McMurtry J.A., Croft B.A. 1997 - Life-styles of phytoseiid mites and their roles in biological control - Annu. Rev. Entomol., 42: 291-321. doi:10.1146/annurev.ento.42.1.291

Meier R., Dikow T. 2004 - Significance of specimen databases from taxonomic revisions for estimating 
and mapping the global species diversity of invertebrates and repatriating reliable specimen data Conserv. Biol., 8(2): 478-488. doi:10.1111/j.15231739.2004.00233.x

Moraes G.J.de, McMurtry J.A., Denmark H.A. 1986 — A catalog of the mite family Phytoseiidae. References to taxonomy, synonymy, distribution and habitat - EMBRAPA - DDT, pp. 353.

Moraes G.J., McMurtry J.A., Denmark H.A., Campos C.B. 2004 - A revised catalog of the mite family Phytoseiidae - Zootaxa, 434: 1-494.

Okassa M., Tixier M.-S., Cheval B., Kreiter S. 2009 Molecular and morphological evidence for a new species status within the genus Euseius (Acari: Phytoseiidae): consequences for taxonomy - Can. J. Zool., 87: 689-698. doi:10.1139/Z09-057

Okassa M., Tixier M.-S., Kreiter S. 2010 - The use of two mitochondrial DNA fragments (12S rDNA and Cytb mtDNA) for assessing the diagnosis of Phytoseiulus persimilis Athias-Henriot and Phytoseiulus macropilis (Banks) (Acari: Phytoseiidae) - Exp. Appl. Acarol., 52: 291-303. doi:10.1007/s10493-010-9364-x

Papadoulis G.T., Emmanouel N.G., Kapaxidi E.V. 2009 Phytoseiidae of Greece and Cyprus (Acari: Mesostigmata) - Indira Publishing House, Michigan, USA. pp. 200.

Rahmani H., Kamali K., Faraji, F. 2010 - Predatory mite fauna of Phytoseiidae of northwest Iran (Acari: Mesostigmata) - Turk. J. Zool., 34: 497-508.

Rowell H.J., Chant D.A., Hansell R.I.C. 1978 — The determination of setal homologies and setal patterns on the dorsal shield in the family Phytoseiidae (Acarina: Mesostigmata) - Can. Entomol., 110: 859-876. doi:10.4039/Ent110859-8

Sclater P.L. 1858 - On the general geographical distribution of the members of the class Aves - Zool. J. Linn. Soc., 2: 130-145. doi:10.1111/j.10963642.1858.tb02549.x

Skuhrava M., Skuhravy V. 2009 - Species richness of gall midges (Diptera: Cecidomyiidae) in Europe (West Palaearctic): biogeography and coevolution with host plants - Acta Soc. Zool. Bohem., 73: 87-156.

Tixier M.-S., Ferrero M., Okassa M., Guichou S., Kreiter S. 2010 - Morphological and molecular analyses of four populations of Phytoseiulus longipes (Mesostigmata: Phytoseiidae) in accordance with their feeding behavior - Bull. Entomol. Res., 17: 1-11.

Tixier M.-S., Guichou S., Kreiter S. 2008b - Morphological variation of the species Neoseiulus californicus (McGregor) (Acari: Phytoseiidae): importance for diagnostic reliability and synonymies - Invert. Syst., 22: 453-469.
Tixier M.-S., Kreiter S. 2009 - Arthropods in biodiversity hotspots: the case of the Phytoseiidae (Acari: Mesostigmata) - Biodivers. Conserv., 18: 507-527. doi:10.1007/s10531-008-9517-y

Tixier M.-S., Kreiter S., Barbar Z., Ragusa S., Cheval B. 2006a - The status of two cryptic species: Typhlodromus exhilaratus Ragusa and Typhlodromus phialatus Athias-Henriot (Acari: Phytoseiidae): consequences for taxonomy - Zool.Scr., 35(2): 115-122. doi:10.1111/j.1463-6409.2006.00222.x

Tixier M.-S., Kreiter S., Cheval B., Auger P. 2003 - Morphometric variation between populations of Kampimodromus aberrans (Oudemans) (Acari: Phytoseiidae): implications for the taxonomy of the genus - Invert. Syst., 17: 349-358.

Tixier M.-S., Kreiter S., Ferragut F., Cheval B. 2006b The suspected synonymy of Kampimodromus hmiminaiand Kampimodromus adrianae (Acari: Phytoseiidae): morphological and molecular investigations - Can. J. Zool., 84(8): 1216-1222. doi:10.1139/z06-108

Tixier M.-S., Kreiter S., Moraes G.J. 2008a - Biogeographic distribution of the mites of the family Phytoseiidae (Acari: Mesostigmata) - Biol. J. Linn. Soc., 93: 845-856. doi:10.1111/j.1095-8312.2007.00937.x

Ueckermann E.A., Jalaeian M., Saboori A., Seyedoleslami H. 2009 - Re-description of Typhlodromus (Anthoseius) khosrovensis Arutunjan, First record for Iran (Acari: Phytoseiidae) - Acarologia, 49(1-2): 23-27.

Ueckermann E.A., Loots G.C. 1988 - The African species of the subgenera Anthoseius De Leon and Amblyseius Beriese (Acari: Phytoseiidae) — Entomol. Mem., Dept. Agric. and Water Supply, 73: pp. 168.

Ueckermann E.A., Zannou I.D., Moraes G.J., Oliveira A.R., Hanna R., Yaninek J.S. 2008 - Phytoseiid mites of the tribe Typhlodromini (Acari: Phytoseiidae) from sub-Saharan Africa - Zootaxa, 1901: 1-122.

Wallace A.R. 1876 - The geographical distribution of animals - Smithsonian Institution Press, Washington, pp. 607.

Wang Y.M., Xu J. 1991 - Two new species and two new records of phytoseiid mites from North China (Acari: Phytoseiidae) - Acta Zootaxon. Sinica, 16(2): 186-190.

\section{COPYRIGHT}

$(\mathrm{cc}$ ) EY-No-ND Hernandes et al.. Acarologia is under free license. This open-access article is distributed under the terms of the Creative Commons-BY-NC-ND which permits unrestricted non-commercial use, distribution, and reproduction in any medium, provided the original author and source are credited. 
Hernandes F.A. et al.

\section{APPENDIX 1}

Species of Typhlodromus (Anthoseius) considered and their characteristics for the five morphological characters considered: (I) number of setae on the sternal shield; (II) number of setae on the ventrianal shield; (III) presence of the pores $g v 3$ on the ventrianal shield $(0=$ absent; 1 = present); (IV) number of solenostomes on the dorsal shield; (V) peritreme extremity at the level of $j 1$ (1), between $j 1-j 3$ (2), between $j 3-z 2$ (3) or between $z 4$ and $s 4$ (4); $\mathrm{U}=$ unknown state or condition. 
Acarologia 51(4): 431-448 (2011)

\begin{tabular}{|c|c|c|c|c|c|}
\hline \multirow{2}{*}{ species } & \multicolumn{5}{|c|}{ characters } \\
\hline & $\mathbf{I}$ & II & III & IV & V \\
\hline 1 T. (A.) abboudieius & 3 & 4 & 1 & 5 & 2 \\
\hline $2 T .($ A.) acacia & 3 & 4 & 1 & 4 & 1 \\
\hline 3 T. (A.) acaciae & 3 & 4 & 1 & 5 & 1 \\
\hline $4 T$. (A.) adenensis & 2 & 4 & 0 & U & 2 \\
\hline $5 T$. (A.) admirabilis & 3 & 4 & 1 & $u$ & 1 \\
\hline $6 T$. (A.) aenaulus & 2 & 4 & 1 & U & 2 \\
\hline 7 T. (A.) aestivalis & 2 & 4 & 0 & 5 & 2 \\
\hline $8 T$. (A.) agilis & 3 & 4 & 1 & 5 & 2 \\
\hline $9 T$. (A.) ailanthi & 3 & 4 & 1 & 5 & 1 \\
\hline $10 T$. (A.) aktherecus & 3 & 4 & 1 & 5 & 3 \\
\hline $11 T$. (A.) algonquinensis & 2 & 3 & 1 & 3 & 2 \\
\hline $12 T$. (A.) apoxys & 2 & 4 & 1 & U & 1 \\
\hline 13 T. (A.) applegum & 2 & 4 & 1 & 3 & 1 \\
\hline $14 T$. (A.) argyronamus & 2 & 4 & 0 & 5 & 1 \\
\hline $15 T$. (A.) arizonicus & 3 & 4 & 1 & 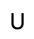 & 1 \\
\hline $16 T$. (A.) arunachalensis & 3 & 4 & 1 & 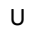 & 1 \\
\hline 17 T. (A.) asperosetosus & 2 & 4 & 1 & U & 1 \\
\hline $18 T$. (A.) astibus & 2 & 4 & 1 & 5 & 1 \\
\hline $19 T$. (A.) asticus & 3 & 4 & 1 & 5 & 1 \\
\hline $20 T$. (A.) athenas & 2 & 4 & 0 & 5 & 1 \\
\hline $21 T$. (A.) atoosae & 2 & 4 & 1 & 5 & 3 \\
\hline $22 T$. (A.) auratus & 2 & 4 & 1 & 5 & 1 \\
\hline $23 T$. (A.) bagdasarjani & 2 & 4 & 0 & 5 & 3 \\
\hline $24 T$. (A.) bakeri & 2 & 4 & 1 & 5 & 1 \\
\hline $25 T$. (A.) balakotiensis & U & 4 & 1 & 1 & 1 \\
\hline $26 T$. (A.) balanites & 3 & 4 & 1 & 5 & 1 \\
\hline 27 T. (A.) bambusae & 2 & 3 & 1 & U & 3 \\
\hline $28 T$. (A.) bambusicolus & 3 & 3 & 1 & $u$ & 1 \\
\hline 29 T. (A.) banahawensis & 3 & 4 & 1 & U & 1 \\
\hline $30 T$. (A.) bergi & 3 & 4 & 1 & 5 & 1 \\
\hline 31 T. (A.) beskaravainyi & 2 & 4 & 0 & 5 & 3 \\
\hline 32 T. (A.) betulae & 3 & 4 & 1 & U & 1 \\
\hline $33 T$. (A.) bifurcuta & 2 & 4 & 1 & $U$ & 1 \\
\hline $34 T$. (A.) bondarenkoi & U & 4 & 1 & 5 & 2 \\
\hline $35 T$. (A.) borealis & 2 & 4 & 1 & U & 1 \\
\hline $36 T$. (A.) brevimedius & 2 & 4 & 1 & U & 1 \\
\hline $37 T$. (A.) brisbanensis & 3 & 4 & 1 & U & 1 \\
\hline $38 T$. (A.) buccalis & 3 & 4 & 1 & 5 & 1 \\
\hline 39 T. (A.) bullatus & 3 & 4 & 1 & 5 & 1 \\
\hline $40 T .($ A.) cannabis & 3 & 4 & 1 & 5 & 1 \\
\hline $41 T$. (A.) capparidis & 2 & 4 & 1 & 5 & 1 \\
\hline $42 T$. (A.) caucasicus & 2 & 4 & 1 & 5 & 1 \\
\hline $43 T$. (A.) caudiglans & 2 & 4 & 1 & 5 & 1 \\
\hline $44 T .($ A.) celastrus & 2 & 4 & 1 & 3 & 1 \\
\hline $45 T$. (A.) cephalochaitosus & 3 & 4 & 1 & U & 2 \\
\hline $46 T$. (A.) cerasicolus & 2 & 4 & 0 & 5 & 2 \\
\hline 47 T. (A.) cervix & 3 & 4 & 1 & U & 1 \\
\hline $48 T .(A$.$) changi$ & 3 & 4 & 0 & U & 1 \\
\hline 49 T. (A.) channabasavannai & 3 & 4 & 1 & U & 1 \\
\hline $50 T$. (A.) charactus & 2 & 3 & 1 & $U$ & 2 \\
\hline 51 T. (A.) chazeaui & 3 & 4 & 1 & $u$ & 1 \\
\hline $52 T$. (A.) chinensis & 3 & 4 & 1 & 5 & 1 \\
\hline $53 T$. (A.) chrysanthemi & U & 4 & 1 & $U$ & U \\
\hline $54 T$. (A.) clairathiasae & U & 4 & 0 & U & 2 \\
\hline $55 T$. (A.) combretum & 2 & 4 & 1 & 4 & 1 \\
\hline $56 T$. (A.) commenticius & 2 & 4 & 1 & 3 & 3 \\
\hline 57 T. (A.) communis & 3 & 4 & 1 & U & U \\
\hline $58 T$. (A.) concavus & 2 & 4 & 1 & U & 2 \\
\hline 59 T. (A.) coniferculus & 2 & 4 & 1 & 5 & 1 \\
\hline $60 T$. (A.) constrictus & 3 & 4 & 1 & 5 & 1 \\
\hline $61 T .(A$.$) coryli$ & 3 & 4 & 1 & 5 & 3 \\
\hline
\end{tabular}

\begin{tabular}{|c|c|c|c|c|c|c|}
\hline \multirow[t]{2}{*}{ species } & \multicolumn{6}{|c|}{ characters } \\
\hline & $\mathbf{I}$ & II & III & IV & $\mathrm{v}$ & $\sqrt{v}$ \\
\hline $62 T .($ A.) coryphus & $U$ & 4 & 0 & U & 1 & 1 \\
\hline $63 T$. (A.) crassus & 3 & 4 & 1 & 5 & 1 & 1 \\
\hline $64 T .($ A.) cuii & 3 & 4 & 1 & U & 2 & 2 \\
\hline 65 T. (A.) dactylifera & 3 & 4 & 1 & 4 & 1 & 1 \\
\hline 66 T. (A.) dalfardicus & 2 & 4 & 1 & 5 & 2 & 2 \\
\hline 67 T. (A.) dalii & 2 & 4 & 1 & U & 1 & 1 \\
\hline $68 T .($ A.) daresalaami & 2 & 3 & 1 & 4 & 1 & 1 \\
\hline 69 T. (A.) darjeelingensis & 3 & 4 & 1 & $u$ & 1 & 1 \\
\hline 70 T. (A.) dasiphorae & 2 & 3 & 0 & $u$ & 3 & 3 \\
\hline $71 \mathrm{~T}$. (A.) datongensis & 3 & 4 & 1 & U & 1 & 1 \\
\hline 72 T. (A.) deleoni & 2 & 4 & 1 & U & 1 & 1 \\
\hline 73 T. (A.) denarus & 3 & 4 & 1 & 5 & 1 & 1 \\
\hline 74 T. (A.) denheyeri & 3 & 4 & 1 & 5 & 1 & 1 \\
\hline 75 T. (A.) denmarki & 2 & 4 & 1 & U & 4 & 4 \\
\hline 76 T. (A.) diumbokus & 3 & 3 & 0 & $u$ & 3 & 3 \\
\hline 77 T. (A.) divergentis & 3 & 4 & 1 & 4 & 1 & 1 \\
\hline 78 T. (A.) doreenae & 2 & 4 & 1 & U & 2 & 2 \\
\hline 79 T. (A.) dossei & 2 & 4 & 1 & 5 & 2 & 2 \\
\hline 80 T. (A.) drori & 2 & 4 & 0 & 4 & 3 & 3 \\
\hline $81 T$. (A.) drymis & 2 & 4 & 1 & 5 & 1 & 1 \\
\hline $82 T$. (A.) egypticus & 3 & 4 & 1 & $U$ & 1 & 1 \\
\hline 83 T. (A.) elaeis & 3 & 4 & 1 & 5 & 1 & 1 \\
\hline 84 T. (A.) elmassri & 3 & 4 & 0 & 3 & 2 & 2 \\
\hline $85 T$. (A.) eremicus & 3 & 3 & 1 & 5 & 3 & 3 \\
\hline 86 T. (A.) eremitidis & 3 & 4 & 1 & U & 2 & 2 \\
\hline 87 T. (A.) evectus & 2 & 4 & 1 & U & 1 & 1 \\
\hline $88 T$. (A.) februs & 2 & 4 & 1 & 5 & 1 & 1 \\
\hline 89 T. (A.) fleschneri & 3 & 4 & 1 & $u$ & 1 & 1 \\
\hline $90 \mathrm{~T}$. (A.) foenilis & 2 & 4 & 0 & 5 & 2 & 2 \\
\hline $91 \mathrm{~T}$. (A.) foraminosus & 2 & 3 & 1 & $u$ & 3 & 3 \\
\hline 92 T. (A.) fujianensis & 2 & 4 & 1 & U & 1 & 1 \\
\hline $93 T$. (A.) galpinii & 2 & 4 & 1 & 5 & 1 & 1 \\
\hline $94 T$. (A.) galummatus & 3 & 4 & 1 & 3 & 1 & 1 \\
\hline 95 T. (A.) gameilus & 2 & 4 & 1 & U & 1 & 1 \\
\hline 96 T. (A.) gardeniae & 2 & 4 & 1 & 5 & 1 & 1 \\
\hline 97 T. (A.) garhwalicus & 3 & 4 & 1 & $u$ & 1 & 1 \\
\hline $98 T$. (A.) georgicus & 3 & 4 & 1 & 5 & U & $\mathrm{J}$ \\
\hline 99 T. (A.) ghanaensis & $\mathrm{U}$ & 4 & 1 & 5 & 1 & 1 \\
\hline 100 T. (A.) ghanii & 2 & 4 & 1 & 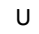 & 1 & 1 \\
\hline 101 T. (A.) gopali & 3 & 4 & 1 & 5 & 1 & 1 \\
\hline 102 T. (A.)gouaniae & 3 & 4 & 1 & 5 & 1 & 1 \\
\hline 103 T. (A.) gracilentus & 3 & 4 & 1 & U & 1 & 1 \\
\hline 104 T. (A.) grastis & 2 & 4 & 1 & 5 & 1 & 1 \\
\hline 105 T. (A.) gressitti & 3 & 4 & 1 & $u$ & 1 & 1 \\
\hline 106 T.(A.) grewiae & $U$ & 3 & 1 & 5 & 1 & 1 \\
\hline 107 T. (A.) guangdongensis & 3 & 4 & 1 & $u$ & 1 & 1 \\
\hline 108 T.(A.) guangxiensis & 3 & 4 & 1 & U & 1 & 1 \\
\hline 109 T. (A.) gulingensis & 3 & 4 & 0 & $u$ & 1 & 1 \\
\hline $110 T$. (A.) gutierrezi & 3 & 4 & 1 & 5 & 1 & 1 \\
\hline $111 T .($ A.) hadii & 3 & 4 & 1 & $u$ & 3 & 3 \\
\hline 112 T. (A.) hadzhievi & $U$ & 4 & 0 & 5 & 2 & 2 \\
\hline 113 T. (A.) haiastanius & 2 & 3 & 1 & U & 4 & 4 \\
\hline 114 T. (A.) halinae & 2 & 4 & 1 & 5 & 2 & 2 \\
\hline 115 T. (A.) haramotoi & 3 & 4 & 1 & U & 1 & 1 \\
\hline $116 T$. (A.) hartlandrowei & 2 & 3 & 1 & 5 & 2 & 2 \\
\hline 117 T. (A.) hebetis & 2 & 3 & 1 & U & 2 & 2 \\
\hline 118 T. (A.) hibernus & 3 & 4 & 1 & 5 & 2 & 2 \\
\hline 119 T. (A.) higoensis & 3 & 4 & 1 & 5 & 1 & 1 \\
\hline 120 T. (A.) himalayensis & 3 & 4 & 0 & U & 1 & 1 \\
\hline 121 T. (A.) hirashimai & 3 & 4 & 1 & 5 & 1 & 1 \\
\hline 122 T. (A.) homalii & $U$ & 4 & 1 & U & 1 & 1 \\
\hline
\end{tabular}




\begin{tabular}{|c|c|c|c|c|c|}
\hline \multirow[t]{2}{*}{ species } & \multicolumn{5}{|c|}{ characters } \\
\hline & 1 & II & & & v \\
\hline 123 T. (A.) hui & 3 & 4 & 1 & $\bar{U}$ & 1 \\
\hline $124 T$. (A.) hungaricus & $\mathrm{u}$ & 4 & 0 & u & 3 \\
\hline $125 \mathrm{~T}$. (A.) ilehoensis & 2 & 4 & 1 & $\mathrm{u}$ & 1 \\
\hline $126 T$. (A.) ilicis & 2 & 2 & 0 & $\mathrm{u}$ & 3 \\
\hline $127 T$. . (A.) incasus & 3 & 4 & 1 & 3 & 1 \\
\hline $128 T$. (A.) incertus & u & U & u & 5 & 3 \\
\hline $129 T$. (A.) incisivus & 2 & 4 & 1 & 5 & 1 \\
\hline $130 T$. (A.) inopinatus & 2 & 4 & 1 & 3 & 3 \\
\hline 131 T. (A.) inops & 2 & 4 & 0 & u & 1 \\
\hline $132 T$. (A.) insularis & 3 & 4 & 1 & u & 1 \\
\hline $133 T$. (A.) intercalaris & 2 & 3 & 1 & 3 & 4 \\
\hline $134 T$. (A.) intermedius & 2 & 4 & 1 & $\mathrm{u}$ & 1 \\
\hline $135 \mathrm{~T}$. (A.) invectus & 2 & 3 & 1 & 3 & 4 \\
\hline $136 \mathrm{~T}$. (A.) involutus & 2 & 4 & 1 & 5 & 1 \\
\hline $137 T$. (A.) iranensis & 2 & 4 & 0 & 3 & 4 \\
\hline $138 \mathrm{~T}$. (A.) johannae & 2 & 4 & 1 & 5 & 1 \\
\hline $139 T$. (A.) jordanis & 2 & 4 & 0 & 5 & 3 \\
\hline $140 T$. (A.) kadonoi & 2 & 4 & 1 & 5 & 3 \\
\hline $141 T$. (A.) kazachstanicus & 2 & 4 & 1 & 3 & 2 \\
\hline 142 T.(A.) kazimiae & 2 & 4 & 1 & 5 & 1 \\
\hline $143 T$ T. (A.) kenyae & u & 4 & 1 & 5 & 1 \\
\hline $144 T$. (A.) kerkirae & 2 & 4 & 1 & 5 & 1 \\
\hline $145 T$. (A.) khosrovensis & 2 & 4 & 0 & 4 & 4 \\
\hline $146 T$. (A.) kiambuensis & 3 & 4 & 1 & $\mathrm{u}$ & 1 \\
\hline 147 T. (A.) kikuyuensis & 3 & 4 & 1 & 5 & 2 \\
\hline $148 T$. (A.) kirinyagae & 2 & 4 & 1 & $\mathrm{u}$ & 1 \\
\hline 149 T. (A.) kiso & 3 & 4 & 1 & 5 & 1 \\
\hline $150 T$. (A.) kodaikanalensis & 3 & 4 & 1 & $\mathrm{u}$ & 1 \\
\hline 151 T. (A.) kolodochkai & 2 & 3 & 0 & 3 & 4 \\
\hline 152 T. (A.) krimbasi & u & 4 & 1 & 5 & 1 \\
\hline $153 T$. (A.) kutabus & 3 & 3 & 1 & 5 & 2 \\
\hline 154 T. (A.) kuznetsovi & 2 & 4 & 1 & 4 & 1 \\
\hline $155 T$. (A.) lalazariensis & 3 & 4 & 1 & 5 & 2 \\
\hline $156 T$. (A.) lanyuensis & 3 & 4 & 1 & $\mathrm{u}$ & 1 \\
\hline 157 T. (A.) lataniae & 3 & 4 & 0 & u & 1 \\
\hline $158 T$. (A.) lateris & 3 & 4 & $\mathrm{u}$ & $\mathrm{u}$ & 1 \\
\hline $159 \mathrm{~T}$. (A.) leilaseius & 2 & 4 & 1 & u & 1 \\
\hline $160 \mathrm{~T}$. (A.) libitus & 3 & 4 & 1 & 5 & 1 \\
\hline $161 T$. (A.) limitatus & $\mathrm{u}$ & $u$ & $\mathrm{u}$ & u & 1 \\
\hline 162 T. (A.) limurus & 2 & 4 & 1 & u & 1 \\
\hline 163 T. (A.) linzhiensis & 2 & 4 & 1 & u & 1 \\
\hline $164 T$. (A.) lobatus & 3 & 4 & 1 & 5 & 1 \\
\hline $165 T$. (A.) longa & 2 & 4 & 1 & $\mathrm{u}$ & 1 \\
\hline $166 T$. (A.) longicervix & 3 & 4 & 1 & u & 1 \\
\hline 167 T. (A.) lootsi & 2 & 4 & 0 & 5 & 1 \\
\hline $168 T$. (A.) loralaiana & 2 & 4 & 1 & u & 1 \\
\hline 169 T. (A.) lushanensis & 3 & 4 & 1 & 3 & 1 \\
\hline 170 T. (A.) luzonensis & 2 & 4 & 1 & 2 & 1 \\
\hline 171 T. (A.) machaon & 2 & 4 & 1 & $u$ & 1 \\
\hline 172 T.(A.) macroides & 3 & 4 & 1 & 5 & 1 \\
\hline 173 T. (A.) macrum & u & u & u & u & $\mathrm{u}$ \\
\hline 174 T. (A.) majumderi & 3 & 3 & 1 & u & 1 \\
\hline 175 T. (A.) makuyus & 2 & 4 & 1 & 5 & 1 \\
\hline $176 T$. (A.) malawiensis & 2 & 4 & 1 & u & 1 \\
\hline 177 T. (A.) malicolus & 2 & 4 & 1 & 5 & 2 \\
\hline $178 T$. (A.) mangiferus & 3 & 4 & 1 & 4 & 1 \\
\hline 179 T. (A.) manipurensis & 3 & 4 & 1 & 2 & 1 \\
\hline 180 T. (A.) maracus & 3 & 4 & 1 & u & 1 \\
\hline $181 T$. (A.) marinus & 3 & 4 & 1 & 5 & 1 \\
\hline 182 T. (A.) masai & 2 & 4 & 1 & u & 1 \\
\hline $183 \mathrm{~T}$. (A.) maspalomensis & 2 & 4 & 0 & 5 & 2 \\
\hline
\end{tabular}

\begin{tabular}{|c|c|c|c|c|c|}
\hline \multirow[t]{2}{*}{ species } & \multicolumn{5}{|c|}{ characters } \\
\hline & I & II & & & $\mathrm{v}$ \\
\hline $184 T$. (A.) matthyssei & 2 & 4 & 1 & 5 & 1 \\
\hline $185 \mathrm{~T}$. (A.) meerutensis & 2 & 4 & 1 & u & u \\
\hline $186 T$. (A.) meritus & 3 & 4 & 1 & 5 & 1 \\
\hline 187 T. (A.) mesasiaticus & 2 & 3 & 0 & 3 & u \\
\hline $188 \mathrm{~T}$. (A.) michaeli & 3 & 4 & 1 & 5 & 1 \\
\hline 189 T. (A.) microbullatus & 2 & 4 & 1 & 5 & 1 \\
\hline $190 T$. (A.) miyarai & 3 & 4 & 1 & u & 1 \\
\hline $191 \mathrm{~T}$. (A.) monosetus & 3 & 2 & 0 & u & 1 \\
\hline $192 T$. (A.) montanus & 2 & 4 & 1 & 4 & 4 \\
\hline 193 T. (A.) mori & 3 & 4 & 1 & u & 1 \\
\hline 194 T. (A.) muliebris & 3 & 4 & 1 & 5 & 1 \\
\hline 195 T. (A.) namaquaensis & 2 & 4 & 0 & 5 & 1 \\
\hline 196 T. (A.) ndibu & 3 & 4 & 1 & 4 & 1 \\
\hline 197 T. (A.) neobakeri & 2 & 4 & 1 & u & 1 \\
\hline 198 T. (A.) neocelastrus & 2 & 4 & 1 & $\mathrm{u}$ & 1 \\
\hline 199 T. (A.) neocrassus & 2 & 4 & 0 & $\mathrm{u}$ & 1 \\
\hline $200 T$. (A.) neogutierrezi & 3 & 4 & 1 & 5 & 1 \\
\hline 201 T. (A.) neohartlandrowei & 2 & 3 & 1 & 5 & 2 \\
\hline 202 T. (A.) neomichaeli & 2 & 4 & 1 & 5 & 1 \\
\hline 203 T. (A.) neondibu & 2 & 4 & 1 & u & 1 \\
\hline 204 T. (A.) neorhenanus & 3 & 4 & 1 & $u$ & u \\
\hline $205 T$. (A.) neoterrulentis & 3 & 4 & 1 & 5 & 1 \\
\hline $206 T$. (A.) neotransvaalensis & 3 & 4 & 1 & $\mathrm{u}$ & 1 \\
\hline 207 T. (A.) neyshabouris & 2 & 4 & 1 & 3 & 4 \\
\hline $208 T$. (A.) nilgiriensis & 3 & 4 & 1 & $\mathrm{u}$ & 1 \\
\hline 209 T. (A.) njorogoeus & 3 & 4 & 1 & $\mathrm{u}$ & 1 \\
\hline $210 T$. (A.) nobilis & 2 & 4 & 1 & 4 & 2 \\
\hline $211 T$. (А.) nоonus & 3 & 2 & 1 & 6 & 3 \\
\hline $212 T$. (A.) nyahururus & 2 & 4 & 1 & $\mathrm{u}$ & 1 \\
\hline $213 T$. (A.) oasis & 3 & 4 & 0 & 5 & 1 \\
\hline 214 T. (A.) obesus & 2 & 4 & 1 & $\mathrm{u}$ & 1 \\
\hline $215 T$. (A.) occiduus & $\mathrm{u}$ & 4 & 1 & 5 & 1 \\
\hline $216 T$. (A.) octavus & 3 & 4 & 1 & 3 & 1 \\
\hline $217 T$. (A.) ordinatus & 2 & 3 & 1 & 3 & 4 \\
\hline $218 T$. (A.) orientalis & 3 & 4 & 1 & $\mathrm{u}$ & 1 \\
\hline $219 T$. (A.) orissaensis & 3 & 4 & 0 & $u$ & $\mathrm{u}$ \\
\hline 220 T. (A.) ornatulus & 3 & 4 & 1 & $u$ & 1 \\
\hline $221 T$. (A.) ornatus & 2 & 4 & 1 & $u$ & 1 \\
\hline 222 T. (A.) paganus & 2 & 4 & 1 & 5 & 1 \\
\hline 223 T. (A.) paraevectus & 2 & 4 & 1 & 4 & 1 \\
\hline $224 T$. (A.) parinopinatus & u & 4 & 1 & 3 & 3 \\
\hline 225 T. (A.) pegazzani & 2 & 4 & 1 & 5 & 3 \\
\hline $226 T$. (A.) persianus & 2 & 4 & 1 & 5 & 1 \\
\hline 227 T. (A.) persicus & 3 & 4 & 1 & $\mathrm{u}$ & u \\
\hline $228 T$. (A.) philippinensis & 3 & 4 & 1 & 5 & 1 \\
\hline 229 T. (A.) pineus & 3 & 4 & 1 & $u$ & 1 \\
\hline 230 T. (A.) pirianykae & 2 & 4 & 1 & 5 & 1 \\
\hline $231 T$. (A.) platycladus & 2 & 4 & 1 & $\mathrm{u}$ & 1 \\
\hline 232 T. (A.) ponticus & 2 & 4 & 1 & 5 & 1 \\
\hline 233 T. (A.) porathi & 3 & 4 & 0 & 4 & 2 \\
\hline 234 T. (A.) porus & 3 & 4 & 1 & 5 & 1 \\
\hline $235 T$. (A.) povtari & 2 & 2 & 0 & $\mathrm{u}$ & 1 \\
\hline $236 T$. (A.) praeacutus & 2 & 4 & 1 & 5 & 1 \\
\hline 237 T. (A.) pruni & 3 & 4 & 1 & 7 & 1 \\
\hline 238 T. (A.) pseudoserrulatus & 3 & 4 & 1 & $\mathrm{u}$ & 1 \\
\hline 239 T. (A.) psyllakisi & 2 & 4 & 1 & 4 & $\mathrm{u}$ \\
\hline $240 T$. (A.) qianshanensis & 3 & 4 & 1 & $u$ & 1 \\
\hline $241 \mathrm{~T}$. (A.) quadratoides & 3 & 4 & 1 & u & 1 \\
\hline 242 T. (A.) quadratus & 2 & 4 & 1 & $\mathrm{u}$ & 1 \\
\hline $243 T$. (A.) rapidus & u & 4 & 1 & 5 & 1 \\
\hline 244 T. (A.) rarus & 2 & 4 & 1 & 4 & 3 \\
\hline
\end{tabular}


Acarologia 51(4): 431-448 (2011)

\begin{tabular}{|c|c|c|c|c|c|}
\hline \multirow[t]{2}{*}{ species } & \multicolumn{5}{|c|}{ characters } \\
\hline & $\mathbf{I}$ & II & III & IV & V \\
\hline $245 T$. (A.) rasilis & 2 & 4 & 1 & 5 & 1 \\
\hline $246 T$. (A.) recki & 2 & 4 & 0 & 3 & 3 \\
\hline 247 T. (A.) religiosus & 3 & 4 & 1 & 5 & 1 \\
\hline $248 T$. (A.) repens & 2 & 4 & 1 & 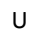 & 3 \\
\hline $249 T$. (A.) rhenanoides & 2 & 4 & 1 & 5 & 2 \\
\hline 250 T. (A.) rhenanus & 2 & 4 & 1 & 5 & 3 \\
\hline $251 T$. (A.) rhododendroni & 3 & 4 & 1 & $u$ & 1 \\
\hline $252 T$. (A.) ribei & $u$ & $u$ & $\mathrm{U}$ & $u$ & $\mathrm{U}$ \\
\hline 253 T. (A.) richteri Karg & $u$ & 4 & 1 & 4 & 1 \\
\hline $254 T$. (A.) rickeri & 3 & 4 & 1 & $u$ & 2 \\
\hline $255 T$. (A.) rivulus & $u$ & 4 & 1 & U & 1 \\
\hline $256 T$. (A.) rodriguezi & 2 & 3 & 0 & 3 & 4 \\
\hline $257 T$. (A.) rubetum & $u$ & $u$ & $\mathrm{u}$ & $u$ & $\mathrm{U}$ \\
\hline $258 T$. (A.) ruiru & 2 & 4 & 1 & 5 & 1 \\
\hline $259 T$. (A.) ryukyuensis & 2 & 4 & 1 & $u$ & 1 \\
\hline $260 T$. (A.) saevus & 2 & 4 & 1 & 5 & 1 \\
\hline $261 T$. (A.) salviae & 2 & 4 & 1 & 5 & 1 \\
\hline $262 T$. (A.) samliensis & 3 & 4 & 1 & $u$ & 1 \\
\hline $263 T$. (A.) sapiens & 2 & 4 & 0 & 3 & 4 \\
\hline $264 T$. (A.) serratosus & 3 & 3 & 1 & 5 & 1 \\
\hline $265 T$. (A.) serratus & 2 & 4 & 1 & 1 & 1 \\
\hline $266 T$. (A.) serrulatus & 3 & 4 & 1 & 5 & 1 \\
\hline 267 T. (A.) shibai & 2 & 4 & 0 & 5 & 2 \\
\hline $268 T$. (A.) sica & 3 & 4 & 1 & 4 & 1 \\
\hline $269 T$. (A.) sichirei & 3 & 4 & 1 & $U$ & 1 \\
\hline $270 T$. (A.) sijiensis & 3 & 4 & 0 & $u$ & 1 \\
\hline 271 T. (A.) silvanus & 3 & 4 & 1 & 5 & 1 \\
\hline 272 T. (A.) singularis & 3 & 3 & 1 & 3 & 1 \\
\hline 273 T. (A.) sonprayagensis & 3 & 4 & 0 & 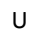 & 1 \\
\hline $274 T$. (A.) spectatus & 2 & 4 & 1 & $u$ & 3 \\
\hline $275 T$. (A.) spiralis & 2 & 4 & 1 & 5 & 1 \\
\hline 276 T. (A.) subarcticus & 2 & 4 & 1 & 5 & 2 \\
\hline 277 T. (A.) subequalis & 2 & 4 & 0 & $u$ & 2 \\
\hline $278 T$. (A.) submarinus & 3 & 4 & 1 & U & 1 \\
\hline 279 T. (A.) subtilis & 3 & 4 & 1 & 5 & 2 \\
\hline $280 T$. (A.) sudanicus & 3 & 4 & 1 & $u$ & 1 \\
\hline $281 T$. (A.) suecicus & 2 & 3 & 1 & $U$ & $\mathrm{U}$ \\
\hline $282 T$. (A.) sycomorus & 3 & 4 & 0 & U & 1 \\
\hline $283 T$. (A.) taishanensis & 3 & 4 & 1 & 5 & 2 \\
\hline $284 T$. (A.) tamaricis & 2 & 4 & 0 & 5 & 3 \\
\hline $285 T$. (A.) tardus & 2 & 3 & 0 & 4 & 3 \\
\hline $286 T$. (A.) tecoma & 2 & 4 & 0 & 1 & 1 \\
\hline 287 T. (A.) tenuis & U & 4 & 1 & 5 & 1 \\
\hline $288 T$. (A.) ternatus & 2 & 3 & 1 & 3 & 3 \\
\hline $289 T$. (A.) terrulentis & 2 & 4 & 1 & 5 & 1 \\
\hline $290 T$. (A.) thailandicus & 3 & 4 & 1 & 5 & 1 \\
\hline 291 T. (A.) theroni & 2 & 4 & 1 & 5 & 1 \\
\hline 292 T. (A.) thesbites & 2 & 4 & 1 & 5 & 1 \\
\hline $293 T$. (A.) torbatejamae & 2 & 4 & 0 & 3 & 4 \\
\hline $294 T$. (A.) totifolianensis & 2 & 4 & 1 & 4 & 1 \\
\hline $295 T$. (A.) transvaalensis & 2 & 3 & 1 & 4 & 3 \\
\hline $296 T$. (A.) tridentiger & 3 & 4 & 1 & U & 1 \\
\hline 297 T. (A.) ulmi & 2 & 4 & 0 & 4 & 3 \\
\hline 298 T. (A.) umbraculus & 2 & 4 & 1 & 5 & 1 \\
\hline 299 T. (A.) umbratus & 3 & 4 & 1 & 6 & 1 \\
\hline $300 T$. (A.) verbenae & 3 & 3 & 0 & 4 & 1 \\
\hline 301 T. (A.) vescus & 3 & 4 & 1 & 5 & 1 \\
\hline 302 T. (A.) viniferae & 2 & 4 & 1 & 3 & 1 \\
\hline 303 T. (A.) votivus & 3 & 4 & 1 & 4 & 1 \\
\hline $304 T$. (A.) vulgaris & 3 & 4 & 1 & 5 & 1 \\
\hline $305 T$. (A.) wainsteini & 2 & 4 & 1 & 5 & 2 \\
\hline
\end{tabular}

\begin{tabular}{|c|c|c|c|c|c|}
\hline \multirow[t]{2}{*}{ species } & \multicolumn{5}{|c|}{ characters } \\
\hline & I & II & III & IV & V \\
\hline 306 T. (A.) werneri & 2 & 4 & 0 & 5 & 2 \\
\hline 307 T. (A.) wonkooi & 2 & 4 & 1 & 5 & 1 \\
\hline 308 T. (A.) wrenschae & 2 & 4 & 1 & 5 & 1 \\
\hline 309 T. (A.) xingchengensis & 2 & 4 & 1 & $\mathrm{U}$ & U \\
\hline $310 T .(A) x i n i$. & 2 & 3 & 0 & $\mathrm{U}$ & 1 \\
\hline $311 T$. (A.) xinjiangensis & 3 & 3 & 1 & $U$ & 4 \\
\hline $312 T$. (A.) xiufui & 3 & 4 & 1 & $\mathrm{U}$ & 1 \\
\hline $313 T$. (A.) xizangensis & 3 & 4 & 1 & $\mathrm{U}$ & 1 \\
\hline $314 T$. (A.) yamashitai & 3 & 4 & 1 & 3 & 1 \\
\hline 315 T. (A.) yasminae & 2 & 4 & 1 & 5 & 2 \\
\hline $316 T$. (A.) yasumatsui & 2 & 4 & 1 & $\mathrm{U}$ & 1 \\
\hline 317 T. (A.) yinchuanensis & 2 & 4 & 1 & $\mathrm{U}$ & 1 \\
\hline $318 T$. (A.) zafari & U & 4 & 1 & 1 & 1 \\
\hline 319 T. (A.) zhangyensis & 2 & 4 & 1 & $U$ & 4 \\
\hline 320 T. (A.) zhaoi & 3 & 4 & 1 & $\mathrm{U}$ & 1 \\
\hline
\end{tabular}


